\title{
The Reference Significance of New Public Management to China's Administrative Management Reform
}

\author{
Zhang Sinan \\ The College of Arts and Sciences \\ Yunnan Normal University \\ KunMing, China \\ sinan217@163.com
}

\begin{abstract}
This paper summarizes the basic content of the new public management thought, and summarizes its main points. Based on the problems of China's current administrative system and economic system reform, this paper discusses the necessity of China's administrative management reform to learn from the new public management thought. The author puts forward the points that should be used for the actual needs of China's administrative reform, highlighting the characteristics of selectively referring and absorbing Western new public management ideas.
\end{abstract}

Keywords-reference significance, new public management, china's administrative management

\section{INTRODUCTION}

New public management first appeared in Western countries, and the United Kingdom was the first country to propose new public management. Subsequently, Australia, the United States, New Zealand and other countries also implemented new public management models. There is no reason for the emergence and prosperity of new public management in Western countries. Since the 1970s, due to the oil crisis in many western countries, the national economy has been severely frustrated, and the burden of social welfare has increased, which has intensified the economic crisis. The national fiscal revenue has been greatly reduced, and countries have experienced fiscal deficits to some extent. Second, since the Second World War, governments have continuously expanded their scale and expanded their functions, resulting in excessive government personnel and increased fiscal expenditure. In addition, the technological revolution and the development of information technology have also prompted Western countries to change the government management model. Under the joint influence of these factors, new public management came into being.

What is new in the new public management compared to the traditional management model? As a proponent of the concept of new public management, Professor Hood pointed out that new public management is a collective term for new ways and methods of applying administrative reform. Gebler and Osborne called it "enterprise government." In the report, the Western government summarized some important components of new public management, including effects, market methods, cost-effectiveness, services, and the introduction of competition. Based on the above, it can be concluded that the new public management has two aspects. The first is to use marketization as a tool. New public management advocates the introduction of marketization into administrative management, and the transformation of business methods into privatization and privatization, and the introduction of competition mechanisms in the field of public services. The second is to use the management tools of industrial and commercial enterprises, that is, private companies to learn their management models, take measures such as performance appraisal, decentralized supervision, and information management to continuously improve the management system.

\section{InterpRetation OF New Public Management THOUGHTS}

The traditional administrative management measures are based on the theory of political and administrative dichotomy or bureaucratic administrative management. The new public management thought is different from these two ideas. It is based on modern economics and private enterprise management theory. On the basis of this, based on the theoretical basis, the innovation and development came out. The new public management thought advocates that administrative management can't rely solely on the form of centralized power. It can't rely on supervision and strengthening the responsibility system to improve administrative performance. It advocates that the government can carry out administrative management innovation, and must actively learn from the management ideas and methods. Manage. In the government management, we must actively introduce a competition mechanism, increase the sense of responsibility and work enthusiasm of government personnel through competition, and improve the quality and level of government service to the people. The new public management philosophy emphasizes that government management should conduct administrative innovation management based on market or customer demand to improve political performance. For the time being, the new public management has not yet formed a complete theoretical idea, 
but its influence on administrative management reform is very large.

Specifically, the new public management ideas mainly include the following:

First, advocate repositioning the government and market relations. Government departments should be able to introduce competitive mechanisms to promote the marketization and quasi-commercial development of their internal management, in this way to improve the quality and level of government public services. The new public management thinking believes that the low efficiency of government management is mainly due to the lack of competition mechanism, the introduction of competition mechanism, the use of market forces to transform the government, enabling more private sectors to participate in public services, and achieving inter-departmental competition, which can effectively improve the government. Service level and work efficiency.

Second, it advocates reintegrating the relationship between the state and society. Through community-funded management, outsourcing, public-private partnerships, privatization, etc., the government carries out various forms of service, enabling private institutions to participate, integrate the relationship between the state and society, and achieve diversified management to improve the quality of public goods and Service Level.

Third, the new public management philosophy emphasizes fundamental reforms to the operational mechanisms and operational methods of government organizations. Effectively adjust the highly organized government structure of the government, and decentralized, flat, and networked government organizations, so that government behavior evaluation standards, control methods, and administrative organization methods can be adjusted through reforms. It is necessary to reform the traditional administrative model and the government's operational mechanism.

Fourth, the new public management philosophy advocates strengthening the country's core strategic capabilities to enhance government competitiveness. The government must proactively carry out its work in a flexible and low-cost manner. It can continuously improve the country's core strategic capabilities and enhance the government's competitiveness based on changes in internal and external environments. It must actively build a democratic and legal government management system to promote government affairs.

Fifth, it is advocated that the government should widely adopt successful management methods and management experience of the private sector. Although there are many essential differences between the public sector and the private sector, there are many effective management methods and management techniques in the private sector, and the public sector can actively learn from it. The government must actively absorb the management experience of the private sector and adopt their management methods to improve the level of service.

Sixth, the government must be able to treat citizens as customers and be customer-centric. Provide customers with the opportunity to freely choose a service organization, provide quality services, and improve citizen satisfaction. The exchange between the government and citizens must be changed from the traditional one-way to the two-way.

Seventh, the government should moderately relax strict administrative rules and be able to carry out target control reforms in accordance with performance. The new public management thinking believes that any department and organization needs rules and regulations to ensure the efficiency of the work, but the rules and regulations are too harsh, which will weaken the efficiency of the organization. Therefore, if the government wants to improve its efficiency, it needs to actively adapt to changes in the market environment, reform some strict administrative rules, make it relatively loose, and achieve effective management and target control through performance.

\section{THE NECESSITY OF CHINA'S ADMINISTRATIVE}

MANAGEMENT REFORM TO LEARN FROM THE NEW PUBLIC MANAGEMENT

The new public management thought is a product of the specific political, economic, scientific and technological development conditions of Western society, and reflects the trend and direction of the development of Western public administration. The wave of new public management reforms in Western countries has improved the level of public management in Western countries to a considerable extent, promoted the economic and social development of Western countries, met more public service needs, and enhanced the West.

China is a developing country and a country in which the economic system has shifted from a planned economy to a market economy. Although China's market economy construction has not started for a long time, it has won worldrecognized achievements such as rapid economic growth and continuous improvement of people's living standards. With the development trend of global integration, how to further play the role of the government in improving China's socialist market economy construction, how the government uses market methods to manage public affairs, improve the quality and efficiency of public administration services, and achieve public administration. Modernization is a realistic and urgent issue facing the Chinese people. It is necessary to carry out indepth research and exploration. The market-oriented theory and practice of public administration management reform in Western countries can obviously provide certain experience for China's public administration management reform and play a certain reference role.

Judging from the practice of China's reform and opening up, since the end of the 1970s, China has generally started allround reforms in various fields such as politics, economy, culture, education, and scientific research systems. Among them, the pace of economic system reform is the fastest, creating a path of a socialist market economic system with progressive characteristics. On the one hand, the reform of the economic system puts forward the necessity of reform of the public administration system, and on the other hand, it creates the necessary conditions for this reform. The guiding ideology 
of institutional reform in China at this stage is still mainly the traditional norms of public administration, and there is still a lack of guidelines for new public management that are popular in Western countries. We believe that although China's national conditions and the actual development level of public administration, the basic norms of the traditional public administration model are not completely outdated in China, but this does not exclude some of the ideas we have absorbed and borrowed from the Western New Public Management in the reform. This is because many of the problems faced by countries in the world in public administration reform are common, both in theory and in practice. Therefore, understanding and drawing on the experience and lessons learned in the practice of public administration reform in Western countries is of positive significance to the practice of public administration reform in China.

\section{The Reference Significance of New Public ManAgement to China's ADMinistrative Management REFORM}

Gradually promote the separation of decision-making power and executive power of government functions. The national conditions of China and the Western countries are very different, and they cannot completely separate the government's decision-making power and executive power. However, according to China's national conditions, the government's decision-making and executive functions can be properly separated, retaining the decision-making body's certain control rights to the executing agency, and performing strict management on the executive department, such as performance appraisal, human resource management, legal system management, etc. Supervise and supervise their work, deal with the dereliction of duty seriously, and make it public to the public, to ensure that the executive department truly manages according to law and does practical things for the people.

The government can adopt a market-based model in some public service areas to introduce a competitive mechanism. Many public service areas in our country are controlled by the state alone. The state's financial pressure is relatively large. Some public service areas have many problems, especially the phenomenon of dirty and messy. The people are very dissatisfied with their existence, and this dissatisfaction has a serious impact. Therefore, the state can consider opening up some public service areas within a certain scope, allowing private capital to enter and forming a competitive mechanism. On the one hand, it is conducive to reducing the state's fiscal expenditure and alleviating the country's fiscal pressure. On the other hand, a good competitive mechanism is conducive to improving the level of social public services, better meeting the requirements of the broad masses of the people, and also contributing to government functions. However, while government departments allow private capital to enter the public domain, they must be strictly screened and supervised to ensure that they can truly contribute to public services, rather than blindly accumulating wealth.

Strengthen performance management and deepen management system reform. Performance management is a management system implemented by many companies today.
Through regular performance appraisal of employees, the company keeps abreast of the work of each employee and understands their ability and level of work. Conduct further management training for unqualified employees, and criticize and educate dereliction of duty staff, deduct salary, demotion and even expulsion. This kind of mechanism is conducive to supervising and testing the work of employees. In order not to deduct bonuses and not to be dismissed, they can also be promoted and raised. The employees will do their best to complete the work, which will improve the work efficiency and work quality to a certain extent. . Similarly, government departments should also implement a performance appraisal management system. The government should form a complete performance appraisal system. The main body of the appraisal can be specialized appraisal institutions, professionals, the public, etc. The public officials at all levels of government are assessed. The assessment should be based on the compliance with relevant laws and regulations. The results of the inspection should be publicized so that the people can understand the situation. For those who do not meet the requirements of civil servants, they must be dealt with seriously. If they criticize education, they should be expelled from public office, and they will no longer be hired in the short term. For public servants with outstanding work abilities and doing practical things for the people, appropriate rewards should also be given. This will not only help to test the work of civil servants, improve work efficiency, but also help improve the government's ability to do things and enhance the government's credibility.

Pay attention to the power of the public and involve the people in the administration of the government. China is the country where the people are the masters of the country. Responsibility for the people and serving the people are the basic principles and purposes of the work of the governments at all levels. Therefore, we must pay attention to the demands of the people and actively listen to the opinions of the people. Governments at all levels should expand the channels for people to participate in government work management, properly disclose the work of the government, allow the people to participate more in the administration of the government, and supervise the work of the government with the help of the public. This will help deepen management.

Transform government functions and build a serviceoriented government. New public management requires the government to enhance the customer awareness of services, focus on the people, provide diverse social needs for the people, and improve the quality of government services. In the specific administrative work, the government should gradually open up the government affairs, adopt a diversified form of service, and satisfy the people's requirements as fast and as fast as possible. In addition, it is necessary to establish an evaluation mechanism for government work, let the people evaluate the government work, and conduct a comprehensive inspection of those departments who have been complained by the masses of the people. Once they have confirmed that they have dereliction of duty, they must be seriously dealt with. 


\section{CONCLUSION}

After more than one hundred years of development, the public administration thoughts of western developed countries have formed a complete set of perfect legal systems and regulations. Therefore, the new public management as the guiding ideology of reform is in line with its development trend. In practice, we can selectively learn from and absorb Western new public management ideas.

\section{REFERENCES}

[1] Ding Yu. On the Significance of Chinese Government Management System Innovation from the Perspective of Good Governance [J]. Journal of Wuhan Metallurgical Management Cadre College. 2009(03).

[2] He Minjie. Promoting the transformation of economic development mode with admin istrative system reform [N]. People's Daily. 2011 (007).

[3] Geng Chunlei, Wang Jianwei. Research on the Path of Administrative Management Reform in China[J]. China Urban Economy. 2011(26).

[4] Zhang Li. Research on the market-oriented reform of govern ment public services in China [D]. Southwestern University of Finance and Economics, 2005.

[5] Li Ting. Analysis of the New Public Management Model for China's Administrative Reform[J]. Legal System, 2011, (8). 